\title{
Odpowiedzialność za naruszenie międzynarodowego prawa humanitarnego przez siły pokojowe Organizacji Narodów Zjednoczonych
}

\section{Wprowadzenie}

Fundamentalną zasadą operacji pokojowych Organizacji Narodów Zjednoczonych (ONZ) jest respektowanie trzech podstawowych reguł: (1) bezstronności - co nie oznacza neutralności, (2) użycia siły tylko w obronie własnej - co w późniejszym okresie zostało rozszerzone do możliwości użycia siły również w obronie mandatu, oraz (3) zgoda państwa goszczącego na obecność na swoim terytorium sił ONZ ${ }^{1}$.

Zgodnie z rozdziałem VI Karty Narodów Zjednoczonych (NZ) operacje pokojowe to działania wielonarodowych sił wojskowych i cywilnych pod nadzorem ONZ, których celem jest rozwiązywanie konfliktów wewnętrznych lub międzynarodowych. Do niedawna do zadań mandatowych takich operacji należało między innymi: wprowadzanie lub nadzorowanie realizacji postanowień pokojowych, rozdzielanie wojsk, kontrolowanie stref buforowych czy zabezpieczanie pomocy humanitarnej.

Współczesne operacje pokojowe na podstawie rozdziału VI Karty NZ otrzymują mandaty, które znacznie wykraczają poza przyjęty dotychczas schemat ich działania, autoryzując je do bardziej aktywnej

* Jacek Stochel, dr, Uniwersytet Marii Curie-Skłodowskiej w Lublinie, e-mail: j.stochel@umcs.pl, https://orcid.org/0000-0002-2685-4296.

${ }^{1}$ United Nations Principles and Guidelines, Department of Peacekeeping Operations, 2008, https://peacekeeping.un.org/sites/default/files/capstone_eng_0.pdf (dostęp: 1 II 2020); M. Both, T. Dorschel, The UN Peacekeeping Experience, w: The Handbook of the Law of Visiting Forces, pod red. D. Flecka, Oxford 2001, s. 489. 
działalności, dając uprawnienie do użycia wszelkich możliwych środków w celu ich realizacji ${ }^{2}$. Choć prawo do użycia siły obejmuje także użycie jej w obronie mandatu, zadania sił pokojowych ONZ mogą w skrajnych przypadkach przekraczać minimalistyczne użycie siły, stawiając je w sytuacji uznania za stronę konfliktu.

Odrębną kategorią aktywności ONZ jest tworzenie operacji na mocy rozdziału VII Karty NZ - tzw. operacji wymuszania pokoju. W przeszłości operacje takie były przeprowadzane pod auspicjami ONZ, pod jej kontrola ale nie kierownictwem. Oznaczało to, że Rada Bezpieczeństwa autoryzowała użycie sił zbrojnych przez państwa, koalicje międzynarodowe czy inne organizacje międzynarodowe ${ }^{3}$. Wielość konfliktów, ich złożoność, niechęć bądź brak możliwości angażowania podmiotów zewnętrznych sprawiły, że organizacja zaczęła również wysyłać "swoje” misje na mocy rozdziału VII Karty NZ ${ }^{4}$. O ile w przypadku autoryzowania misji realizowanej przez podmioty zewnętrzne kwestia stosowania prawa, w tym norm międzynarodowego prawa humanitarnego (MPH), oraz ewentualna odpowiedzialność za jego naruszenie pozostawały w gestii państw, koalicji czy innych organizacji międzynarodowych, o tyle w przypadku misji będących pod bezpośrednią kontrolą i kierownictwem ${ }^{5}$ organizacji odpowiedzialność za złamanie norm prawa międzynarodowego przez te siły stała się kwestią problematyczną. Konsekwencją takiego zaangażowania ONZ było wysuwanie postulatu, że wojska ONZ mogą się stać stroną konfliktu, co oznacza konieczność respektowania przez nie MPH oraz ponoszenia odpowiedzialności za jego naruszenie ${ }^{6}$.

${ }^{2} \mathrm{Na}$ przykład Rezolucja Rady Bezpieczeństwa Narodów Zjednoczonych (RB ONZ) 2149 z dnia 10 IV 2014 r., S/Res./2149, dotycząca zadań mandatowych misji MINUSCA w Republice Środkowej Afryki czy Rezolucja RB ONZ 2100 z dnia 24 IV 2013 r., S/Res./2100, dotycząca misji MINUSMA w Mali, www.undocs.org (dostęp: 1 II 2020).

${ }^{3}$ Na przykład Rezolucja RB ONZ 1244 z dnia 10 VI 2002 r., S/Res./1244 (Annex 2) dotycząca zaangażowania NATO w Kosowie; Rezolucja RB ONZ 1386 z dnia 20 XII 2001 r., S/Res./1386, dotycząca powołania misji ISAF w Afganistanie; Rezolucja 1441 z dnia 8 XI 2002 r., S/Res./1441, dotycząca misji koalicyjnej w Iraku, www.undocs.org (dostęp: 1 II 2020).

${ }^{4}$ Przykładem sa misje: MONUSCO w Kongu MINUSCA w Republice Środkowej Afryki czy MINUSMA w Mali.

${ }^{5} \mathrm{~W}$ kwestii interpretacji pojęć zob. $\$ 7$ komentarza do art. 17 Artykutów o międzynarodowej odpowiedzialności państw, "Yearbook of the International Law Commission" 2001, vol. 2, s. 66.

${ }^{6}$ J.E. Fink, From Peacemaking to Peace Enforcement: The Blurring of the Mandate for the Use of Force in Maintaining International Peace and Security, "Maryland Journal of International Law and Trade" 1995, no. 19, s. 35. 
Przypisanie organizacji międzynarodowej odpowiedzialności za naruszenie prawa międzynarodowego jest możliwe tylko wtedy, gdy zostaną spełnione następujące przesłanki: dana organizacja musi mieć podmiotowość międzynarodową ( $w$ analizowanym przypadku włączając także dorozumianą podmiotowość w zakresie stosowania względem sił pokojowych ONZ norm MPH), musi istnieć możliwość przypisania konkretnego działania lub zaniechania organizacji międzynarodowej, a także musi mieć miejsce naruszenie zobowiązania międzynarodowego wiążącego organizację .

Celem artykułu jest udzielenie odpowiedzi na pytanie, czy ONZ jako organizacja może ponosić odpowiedzialność za naruszenie MPH za działania sił pokojowych, a jeśli tak, to jakie okoliczności powinny być spełnione, aby taką odpowiedzialność tej organizacji przypisać. Opracowanie nie udziela natomiast odpowiedzi na pytanie, w jaki sposób tę odpowiedzialność można względem organizacji wyegzekwować, co stanowi odrębny temat analiz.

\section{Obowiązek ONZ do przestrzegania międzynarodowego prawa humanitarnego - aspekt podmiotowy}

Podmiotowość organizacji międzynarodowych w prawie międzynarodowym charakteryzuje się między innymi ponoszeniem przez nie odpowiedzialności za działania lub zaniechania swoich funkcjonariuszy, jeśli szkoda powstała wskutek wykonywania przez nich działalności statutowej. W tej kwestii przywoływana z orzecznictwa Międzynarodowego Trybunału Sprawiedliwości (MTS) w zakresie podmiotowości organizacji międzynarodowych była i nadal pozostaje opinia doradcza w sprawie odszkodowania za szkody poniesione w służbie Narodów Zjednoczonych. MTS w swej opinii doradczej wyraźnie stwierdził, że ONZ może być podmiotem praw i obowiązków wynikających z norm prawa międzynarodowego, jednak podkreślił przy tym, że nie należy traktować ONZ na tych samych zasadach co państwa, a tym bardziej uznawać ONZ za superpaństwo ${ }^{8}$. ONZ nie może zatem mieć takich praw i obowiązków, jakie można przypisać państwom ją tworzącym. Powinna

${ }^{7}$ W. Czapliński, Odpowiedzialność państwa członkowskiego za akty organizacji międzynarodowych, "Ruch Prawniczy, Ekonomiczny i Socjologiczny” 2006, R. 68, z. 2, s. 106.

${ }^{8}$ Advisory Opinion, Reparation for Injuries Suffered in the Service of the United Nations, I.C.J. 174 (Apr. 11, 1949). 
raczej przyjmować na siebie obowiązki oraz korzystać z uprawnień, które są konieczne do wykonywania przez nią funkcji, do których została powołana?.

W odniesieniu do podlegania, a jednocześnie respektowania przez siły ONZ prawa humanitarnego stanowisko podlegało ewolucji. W przeszłości twierdzono, że ani siły pokojowe ONZ, ani też poszczególne państwa wydzielające siły nie są zaangażowane w konflikt zbrojny, a tym samym nie mogą być stroną konfliktu i konsekwentnie nie są związane MPH. Takie stanowisko, pozostające dziś w mniejszości, uzasadniano faktem, że misje są bezstronne, obiektywne, neutralne, działają w imieniu społeczności międzynarodowej, nie można ich więc traktować jako strony konfliktu w rozumieniu Konwencji genewskich (KG) z 1949 r. ${ }^{10}$

Współcześnie wydaje się kwestią oczywista, że ONZ zaangażowana w operację wojskową lub biorąca udział w konflikcie zbrojnym musi stosować się do norm $\mathrm{MPH}^{11}$. Implementacja MPH napotyka jednak na pewne trudności. MPH oparte jest na prawie traktatowym, a także na normach międzynarodowego prawa zwyczajowego. ONZ nie jest stroną żadnych norm traktatowych dotyczących MPH. Wynika to z wielu powodów. Oczywiście, wiele norm nie daje wyraźnie możliwości bycia stroną traktatu organizacji międzynarodowej, gdyż odnoszą się one tylko do państw jako podmiotów prawa międzynarodowego. Niektóre normy stanowią również, że pewne działania ze swej natury mogą być podejmowane wyłącznie przez państwa. Ponadto ONZ, podejmując się aktywności, która wymaga ze swej istoty stosowania MPH,

${ }^{9}$ Omówienie opinii doradczej zob. B. Krzan, Odpowiedzialność państwa członkowskiego z tytułu działalności organizacji międzynarodowych, Wrocław 2013, s. 62. Zob. też S.P. Sheeran, A Constitutional Moment?: United Nations Peacekeeping in the Democratic Republic of Congo, „International Organizations Law Review” 2011, no. 1, s. 66; K.E. Sams, IHL Obligations of the UN in International Missions, w: International Military Missions and International Law, "International Humanitarian Law Series" 2011, t. 31, s. 45.

${ }^{10}$ Konwencje genewskie (Dz.U. 1956 Nr 38, poz. 174); D. Shraga, R. Zacklin, The Applicability of International Humanitarian Law to United Nations Peacekeeping Operations: Conceptual, Legal and Practical Issues, Report to the Symposium on Humanitarian Action and Peacekeeping Operations, 22-24 June 1994, ICRC, Geneva 2004, s. 39-48, i zawarte tam wskazanie ewolucji poglądów.

${ }^{11}$ Niejednokrotnie mandat danej misji literalnie wskazuje, że siły pokojowe ONZ są zobowiązane w swych działaniach do przestrzegania MPH. Dodatkowo Sekretarz Generalny w celu zobowiązania sił pokojowych ONZ do stosowania MPH wydał instrukcje dla sił pokojowych ONZ, zobowiązując je pod pewnymi warunkami do respektowania $\mathrm{MPH}$, zob. Secretary-General's Bulletin on the Observance by United Nations Forces of International Humanitarian Law, UN Doc. ST/SGB/1993/13, 6 August 1999, www.undocs.org (dostęp: 1 II 2020). 
czego najlepszym przykładem jest kierowanie misji pokojowych na terytorium trwającego konfliktu zbrojnego, stara się unikać otwartego twierdzenia o jednostronnym stosowaniu MPH. Deklaruje jedynie, że w trakcie swojej działalności będzie postępować zgodnie z duchem i zasadami $\mathrm{MPH}^{12}$, niejednokrotnie zastrzegając, że działając w imieniu międzynarodowej społeczności, nie powinna być utożsamiana z byciem stroną konfliktu, a tym bardziej władzą okupacyjną zgodnie z postanowieniami $\mathrm{KG}^{13}$.

Jeżeli przyjmiemy zatem, że ONZ na mocy międzynarodowego prawa zwyczajowego może być podmiotem prawa i obowiązków wynikających z prawa międzynarodowego, w tym MPH, powinna także na zasadzie mutatis mutandis respektować normy, które można z samej ich natury zastosować do organizacji i które pozostają w zgodzie z celem i zasadami funkcjonowania organizacji.

\section{Definicja konfliktów zbrojnych i umiejscowienie w nich roli sił pokojowych ONZ}

Rozważania na temat podlegania przez ONZ normom prawa międzynarodowego pod względem podmiotowym należy uznać za zasadne. Niemniej jednak w odniesieniu do MPH istotą podlegania tym normom jest przede wszystkim wypełnienie ich pod względem funkcjonalnym.

Punktem wyjścia do analizy jest rozdzielenie dwóch gałęzi prawa międzynarodowego: ius in bello i ius ad bellum ${ }^{14}$. Prawna podstawa stosowania MPH nie zależy bowiem od spełnienia przesłanek, które dają podstawę prawną do użycia siły, takich jak rezolucje RB ONZ, ale od wypełnienia warunków wynikających z postanowień MPH, w szczególności art. 2 i 3 KG. Praktyczne podejście do kwestii stosowania MPH sprowadza się zatem do określenia, czy siły międzynarodowe, które operują w danej misji, spełnią przesłanki do bycia podmiotem, wobec którego normy MPH mają zastosowanie.

${ }^{12}$ Przykładem mogą być również umowy o statusie misji podpisywane między ONZ a państwem gospodarzem, zob. D. Shraga, The United Nations as an Actor Bound by International Humanitarian Law, "International Peacekeeping” 1998, no. 5.

${ }^{13}$ Zob. R. Murphy, UN Peacekeeping in Lebanon, Somalia and Kosovo: Operations and Legal Issues in Practice, Cambridge 2007, s. 248.

${ }^{14} \mathrm{~K}$. Okimoto, The Distinction and Relationship between Jus ad Bellum and Jus in Bello, Oxford 2011, s. 17; A. Orakhelashvili, Overlap and Convergence: The Interaction Between Jus ad Bellum and Jus in Bello, "Journal of Conflict and Security Law" 2007, no. 12, s. 167-170. 
Tak też jest w przypadku sił pokojowych ONZ. To nie założenia wyrażone w mandacie operacji, ale konkretne działania sił w danej operacji powinny determinować stosowanie przez nie i względem nich $\mathrm{MPH}^{15}$. Przyjęcie założenia o wyłączeniu sił pokojowych ONZ z zakresu podmiotowego MPH, w tym z bycia stroną konfliktu zbrojnego, stworzyłoby dwuznaczną sytuację. Siły pokojowe ONZ spełniałyby określone w MPH warunki uznania za podmiot, przeciw któremu można prowadzić działania zbrojne, atak na takie siły mógłby być jednak uznany za złamanie prawa międzynarodowego. Statut rzymski wyraźnie bowiem stanowi, że zamierzone kierowanie ataków na personel, instalacje, materiały, oddziały lub pojazdy związane z pomocą humanitarną lub misjami pokojowymi (peacekeeping missions) działającymi na podstawie Karty NZ, tak długo, jak są one uprawnione do ochrony przysługującej osobom cywilnym i obiektom cywilnym na podstawie międzynarodowego prawa konfliktów zbrojnych, uznaje się za zbrodnię wojenną ${ }^{16}$. Chcąc dodatkowo wzmocnić ochronę personelu ONZ, z inicjatywy SG ONZ opracowano konwencję dotyczącą bezpieczeństwa członków personelu ONZ. Konwencja w swej treści podobnie nie ma zastosowania do misji wymuszania pokoju (peace enforcement) ustanowionych na mocy Rozdziału VII Karty NZ, w których personel misji jest zaangażowany $\mathrm{w}$ działania przeciwko zorganizowanym siłom zbrojnym, do których mają zastosowanie postanowienia prawa odnoszące się do międzynarodowych konfliktów zbrojnych ${ }^{17}$. Ponadto,

${ }^{15}$ The Interim Law of Armed Conflict Manual, DM 112, Directorate of Legal Services, New Zealand Defence Force, Wellington, New Zealand 1992, § 1902, s. 19; The Law of Land Warfare, United States, FM 27-10, Department of the Army Field Manual, 1956.

${ }^{16}$ Zgodnie z normami MPH ludność cywilna korzysta z ochrony, chyba że bierze bezpośredni udział w działaniach zbrojnych. Pomijając kwestie trudności oceny bezpośredniego udziału ludności cywilnej w działaniach zbrojnych, wielość definicji i przyjętych rozwiązań, oznacza to, że za zbrodnię wojenną uznaje się tylko atak na siły pokojowe ONZ wykonujące zadania w ramach rozdziału VI Karty NZ (peacekeeping), lecz tylko tak długo, jak są uprawnione do ochrony przysługującej osobom cywilnym. Statut nie ma zastosowania do innych działań, np. misji wymuszania pokoju (peace enforcement missions) w ramach rozdziału VII Karty NZ. Zob. Statut rzymski, art. 8 2(b) (iii) - dotyczący konfliktów zbrojnych o charakterze międzynarodowym i odpowiednio w art. 8 2(e)(iii) - dotyczący konfliktów niemiędzynarodowych.

${ }^{17} \mathrm{~W}$ kwestiach szczegółowych zob. Konwencja o bezpieczeństwie personelu Organizacji Narodów Zjednoczonych i personelu współdziałającego sporządzona w Nowym Jorku 9 XII 1994 r. i tam wprowadzone rozszerzenia stosowania Konwencji na inne przypadki, co potęguje niezrozumiałość i chaotyczność ustanowionych norm. Obecnie stroną konwencji są 94 państwa, w tym Polska, https://treaties.un.org/pages/ViewDetails.aspx?src=TREATY \&mtdsg_no=XVIII-8\& chapter=18\&clang=_en (dostęp: 1 II 2020). 
w celu doprecyzowania regulacji prawnomiędzynarodowych i wyraźnego wskazania zakresu stosowania MPH przez siły pokojowe ONZ, Sekretarz Generalny opublikował biuletyn, w którym wskazano, że siły pokojowe ONZ zarówno w trakcie działań egzekucyjnych (enforcement action), jak i w operacjach pokojowych, gdzie użycie siły jest dozwolone w ramach obrony koniecznej, powinny stosować fundamentalne zasady i reguły MPH. Brzmienie art. 1.1 sugeruje, że "fundamentalne" zasady i reguły MPH mają zastosowanie do sił pokojowych ONZ w sytuacji istnienia konfliktu zbrojnego w przypadku, gdy siły pokojowe ONZ są w nim aktywnie zaangażowane jako strona walcząca, do czasu ustania tego zaangażowania. Zdanie drugie artykułu określa zakres funkcjonalny, który rozciąga się zarówno na akcje wymuszenia pokoju (rozdział VII Karty NZ), jak i misji pokojowych, kiedy dozwolone jest użycie sił w obronie koniecznej (Rozdział VI Karty NZ). W zdaniu tym zawarto jednak wyrażenie "odpowiednio" (accordingly), co sugeruje, że w tym przypadku mają zastosowanie również przesłanki, które określono w zdaniu pierwszym, czyli konieczność istnienia konfliktu zbrojnego oraz rozciągnięcie zasad MPH tylko na czas aktywnego zaangażowania jako strona walcząca. Takie brzmienie powoduje, że w przypadku misji pokojowej stabilizacyjnej, gdzie nie mamy do czynienia z konfliktem zbrojnym, np. misja UNIFIL czy UNDOF, normy MPH niekoniecznie muszą być przez sily pokojowe respektowane. Można by zatem wnioskować, że siły pokojowe zobowiązane są do stosowania MPH tylko w przypadku aktywnego zaangażowania jako strona walcząca. Brakuje doprecyzowania pojęcia aktywnego zaangażowania, wobec czego można to pojęcie rozpatrywać w sposób deklaratywny. W takiej sytuacji to siły pokojowe ONZ miałyby decydujący głos w kwestii, czy ich działania należy traktować jako zaangażowanie w konflikt zbrojny, a takie działanie wprowadzałoby trudności w stosowaniu MPH w praktyce ${ }^{18}$.

${ }^{18}$ Zob. United Nations, Secretary-General's Bulletin: Observance by United Nations Forces of International Humanitarian Law, UN Doc. ST/SGB/1999/13, August 6, 1999, a także: O. Engdahl, A Rebuttal to Eric David, "International Review Red Cross” 2014, no. 95, s. 669; S. Sheeran, S. Case, The Intervention Brigade: Legal Issues for the UN in the Democratic Republic of the Congo, International Peace Institute, November 2014, s. 11.

Wprawdzie koncepcja czasowego posiadania statusu kombatanta dla sił pokojowych ONZ była przedmiotem debat trybunałów międzynarodowych (zob. Decision on the Confirmation of Charges (Prosecutor v. Abu Garda), ICC 02/05-02/09, 8 February 2010, $\S 83$, za: Y. Arai-Takahashi, The Intervention Brigade. The Intervention Brigade Within The MONUSCO. The Legal Challenges of Applicability and Application of IHL, "Questions of International Law" 2015, no. 5, s. 18), niemniej jednak zrównanie niezaangażowanych 
Zakładając zatem, że siły pokojowe ONZ są kierowane w miejsca, gdzie trwa lub trwał konflikt zbrojny, należy w pierwszej kolejności ustalić, czy rzeczywiście mamy do czynienia z konfliktem zbrojnym i jakiego rodzaju, przyjmując stosowany w prawie międzynarodowym podział na konflikt zbrojny o charakterze międzynarodowym i niemiędzynarodowym, a następnie przeprowadzić analizę zaangażowania w nim sił pokojowych ONZ.

Do ustalenia istnienia konfliktu międzynarodowego nie jest konieczne prowadzenie poważnych walk czy działań zbrojnych. Istotne jest ustalenie stron konfliktu. Zgodnie z decyzją Międzynarodowego Trybunału Karnego ds. byłej Jugosławii (ICTY) konflikt zbrojny istnieje, ilekroć państwa uciekają się do użycia swoich sił zbrojnych ${ }^{19}$. Międzynarodowy Czerwony Krzyż w oficjalnym komentarzu interpretuje natomiast wspólny art. II Konwencji genewskich w sposób szerszy, twierdząc, że przyczynkiem do stosowania MPH są "różnice powstałe między dwoma państwami i prowadzące do interwencji sił zbrojnych"20.

Nieco trudniej jest określić istnienie konfliktu o charakterze niemiędzynarodowym. Konieczne jest wypełnienie kryteriów ustanowionych w art. 1(2) Protokołu Dodatkowego II ${ }^{21}$ do Konwencji genewskich i art. 8(2)(d) Statutu rzymskiego ${ }^{22}$. Ze względu na brak klarownej definicji tego rodzaju konfliktu należy domniemywać, że istnieje on wtedy,

sił pokojowych ONZ w ramach konfliktu zbrojnego z uprawnieniami ludności cywilnej niebiorącej bezpośredniego udziału w konflikcie zbrojnym może wprowadzać pewien dysonans. Należy przyłączyć się do stanowiska większości przedstawicieli doktryny, że siły pokojowe ONZ są objęte MPH do czasu, kiedy przestaną być stroną konfliktu zbrojnego nie w jednostkowym działaniu, ale w operacji wojskowej jako całości.

${ }^{19}$ Decision on Defence Motion for Interlocutory Appeal on Jurisdiction (Prosecutor v. Tadic), Case No. IT-94-I-AR72, 70 (Int'1 Crim. Trib. for the Former Yugoslavia Oct. 2, 1995).

${ }^{20} \mathrm{~J}$. Picket, Commentary on the Geneva Convention for the Amelioration of the Condition of the Wounded and Sick in Armed Forces in the Field, Geneva 1952, s. 32.

${ }^{21}$ Artykuł 2(1) Protokołu dodatkowego do Konwencji genewskich dotyczaccy ofiar niemiędzynardowych konfliktów zbrojnych podaje definicję negatywną niemiędzynarodowego konfliktu zbrojnego: Niniejszy protokół nie ma zastosowania do takich wewnętrznych napięć i niepokojów, jak: rozruchy, odosobnione i sporadyczne akty przemocy oraz inne działania podobnego rodzaju, które nie są uważane za konflikty zbrojne, zob. Protokoły dodatkowe do Konwencji genewskich z dnia 12 VIII 1949 r.: Protokół I - dotyczący ochrony ofiar międzynarodowych konfliktów zbrojnych oraz dotyczący ochrony ofiar niemiędzynarodowych konfliktów zbrojnych - Protokół II (Dz.U. $1992 \mathrm{Nr}$ 41, poz. 175).

${ }^{22}$ Zgodnie ze Statutem MTK za konflikty zbrojne posiadające charakter niemiędzynarodowy nie można uznać konfliktów, które przejawiają się w postaci wewnętrznych zamieszek i napięć, takich jak bunty oraz odizolowane i sporadyczne akty przemocy lub 
gdy działania osiągną pewien poziom intensywności, który wykracza poza uznanie ich za wewnętrzne niepokoje czy napięcia, które mogą być powszechnie obserwowane w czasie buntów i sporadycznych aktów przemocy ${ }^{23}$. Można zatem przyjąć, że warunki do uznania konfliktu za niemiędzynarodowy są trudniejsze do ustalenia niż postawione zgodnie $\mathrm{z}$ art. 2 Konwencji genewskich dla konfliktów międzynarodowych, gdzie nieistotne są kwestie intensywności i czasu prowadzenia działań zbrojnych, ale wyłącznie zakres podmiotowy ${ }^{24}$.

Generalna tendencja zauważalna w praktyce prowadzi jednak do wniosku, że coraz częściej zaniża się próg intensywności konfliktu, co powoduje wątpliwości, czy mamy do czynienia z konfliktem niemiędzynarodowym czy jeszcze z przypadkiem wewnętrznych niepokojów bądź napięć ${ }^{25}$. Kwestię intensywności konfliktu, w szczególności na potrzeby międzynarodowego prawa zwyczajowego, w literaturze określa się na podstawie decyzji Trybunału ds. byłej Jugosławii w sprawie Prokurator przeciwko Tadic. Trybunał stwierdził, że za konflikt zbrojny o charakterze niemiędzynarodowym należy uznać konflikt, który istnieje, kiedy dochodzi do konfrontacji lub przedłuża się zbrojna przemoc pomiędzy siłami rządowymi a zorganizowanymi grupami zbrojnymi lub między tymi grupami w obrębie państwa ${ }^{26}$. Nie oznacza to jednak, że konflikt winien mieć charakter ciągły, nieprzerwany czy długotrwały ${ }^{27}$. Może on objawiać się w powtarzających się bądź sporadycznych zbrojnych konfrontacjach przeplatanych okresem względnego spokoju ${ }^{28}$. Intensywność konfliktu można oceniać przez wiele czynników, takich jak: liczba potyczek, czas trwania, intensywność indywidualnych konfrontacji,

inne działania o podobnym charakterze, zob. Rzymski Statut Międzynarodowego Trybunału Karnego sporządzony w Rzymie dnia 17 VII 1998 r. (Dz.U. 2003 Nr 78, poz. 708).

${ }^{23}$ Judgment (Prosecutor v. Limaj et al.), Case No. IT-03-66-T (Int'l Crim. Trib. for the Former Yugoslavia 30 XI 2005), § 90; zob. też ICRC, Commentary on the First Geneva Convention: Convention (I) for the Amelioration of the Condition of the Wounded and Sick in Armed Forces in the Field, pod red. J.M. Henckaertsa, 2nd ed., 2016, § 387.

${ }^{24}$ T. Ferraro, The Applicability and Application of International Humanitarian Law to Multinational Force, „International Review of the Red Cross” 2013, vol. 95, s. 575-576.

${ }^{25}$ S. Vité, Typology of Armed Conflicts in International Humanitarian Law: Legal Concepts and Actual Situations "International Review of the Red Cross" 2009, vol. 91, s. 76.

${ }^{26}$ Decision on Defence Motion for Interlocutory Appeal on Jurisdiction (Prosecutor v. Tadic), § 70 .

${ }^{27}$ S. Boelaert-Suominen, Commentary: The Yugoslav Tribunal and the Common Core of Humanitarian Law Applicable to All Conflicts, "Leiden Journal of International Law” 2000, no. 13 , s. 634-635.

${ }^{28}$ T. Ferraro, op. cit., s. 579. 
rodzaj używanego do walk uzbrojenia i sprzętu wojskowego, liczba ofiar, zakres szkód w mieniu, liczba osób, które zmuszone były do opuszczenia strefy walk ze względów bezpieczeństwa, czy analiza konfliktu wskazująca na jego rozprzestrzenianie $\operatorname{się}^{29}$.

Pomimo że postanowienia Konwencji Genewskiej wyraźnie wskazują, iż uzbrojone grupy opozycyjne powinny mieć pewien poziom organizacji, aby móc dokonywać działań o charakterze zbrojnym ${ }^{30}$, Protokół dodatkowy II wprowadza kolejne kryteria i stanowi, że takie grupy zbrojne powinny pozostawać pod dowództwem ${ }^{31}$ i sprawować kontrolę nad częścią terytorium tak, aby być zdolnymi do prowadzenia ciągłych i skoordynowanych operacji wojskowych, oraz przestrzegać prawa międzynarodowego, w tym niniejszego protokołu ${ }^{32}$. Każdy zatem konflikt, w celu uznania go za konflikt o charakterze niemiędzynarodowym, podlega stosownej ocenie w odniesieniu do jego stron, w szczególności niepaństwowych grup zbrojnych oraz zakresu działań.

Funkcjonowanie operacji pokojowej ONZ w miejscu, gdzie trwa konflikt zbrojny, sprowokowało dyskusję dotyczącą tego, jak należy charakteryzować taki konflikt. W doktrynie i literaturze wyrażano pogląd, że zaangażowanie sił pokojowych ONZ w konflikt powoduje „internacjonalizację" konfliktu bez względu na to, kto jest stroną przeciwną ${ }^{33}$. Powyższe stanowisko prezentowane było w szczególności na początku tworzenia misji pokojowych opartych na mandatach, które wymuszały konieczność prowadzenia pewnych działań operacyjnych, a nie tylko obserwacji. Zgodnie z tym poglądem ważne było źródło

${ }^{29}$ Judgment (Trial Chamber) (The Prosecutor v. Boškoski), Case No. IT-04-82-T (Int'l Crim. Trib. for the Former Yugoslavia 10 VII 2008), § 177-193.

${ }^{30}$ Judgment (Prosecutor v. Limaj et al.), Case No. IT-03-66-T (Int'l Crim. Trib. for the Former Yugoslavia 30 XI 2005), § 90; Judgment (Prosecutor v. Haradinaj et al.), Case No IT-04-84-T (Int'1 Crim. Trib. for the Former Yugoslavia 3 IV 2008), § 60.

31 J. Pejic, The Protective Scope of Common Article 3: More Than Meets the Eye, "International Review of the Red Cross" 2011, vol. 93, s. 3-4, 11, 35.

${ }^{32} \mathrm{~W}$ przeciwieństwie do art. 3 Konwencji genewskich Protokół II wyłącza konieczność istnienia konfrontacji pomiędzy niepaństwowymi siłami zbrojnymi. Niemniej jednak art. 1(1) protokołu wyraźnie stwierdza, rozwija i uzupełnia art. 3, wspólny dla Konwencji genewskich z dnia 12 VIII 1949 r., nie zmieniając warunków jego zastosowania.

${ }^{33}$ F. Seyersted, United Nations Forces in the Law of Peace and War, Leyden 1966, s. 213; D. Shraga, The United Nations as an Actor..., s. 74; R. Kolb, Applicability of International Humanitarian Law to Forces Under the Command of an International Organization, w: Report: Expert Meeting on Multinational Peace Operations Applicability of International Humanitarian Law and International Human Rights Law to UN Mandated Forces, pod red. A. Faite'a, J. Labbe Greniera, Geneva 2004, s. 62, https://www.icrc.org/eng/resources/documents/ publication/p0912.htm (dostęp: 1 II 2020). 
uprawnień wydanych siłom pokojowym ONZ, tj. oparte na prawie międzynarodowym i angażujące podmioty w ramach sił pokojowych, które pochodzą z różnych państw. Takie założenie powodowało jednak, że siły pokojowe ONZ zawsze uczestniczyłyby w międzynarodowym konflikcie zbrojnym, a tym samym były zobowiązane do stosowania postanowień odnoszacych się tylko do międzynarodowych konfliktów zbrojnych.

Obecnie przyjmuje się, że w przypadku, gdy siły pokojowe ONZ prowadzą działania przeciw siłom zbrojnym innego państwa, mamy do czynienia z międzynarodowym konfliktem zbrojnym. Taki wniosek płynie z wcześniej przyjętego stanowiska dotyczącego stosowania $\mathrm{MPH}$ względem ONZ, a więc z faktu, że obie walczące strony są podmiotami prawa międzynarodowego posiadającymi zdolność prawnomiędzynarodowa ${ }^{34}$, a ONZ powinna respektować te normy mutatis mutandis. Oczywiste jest, że sił pokojowych ONZ nie można wprost utożsamiać z siłami jakiegokolwiek państwa albo siłami koalicyjnymi państw. ONZ zawsze akcentuje, że wydzielone siły pokojowe podlegają operacyjnej kontroli dowództwa misji, które jest organem pomocniczym organizacji, ich podmiotowość jest odrębna od narodowych kontyngentów misji, a w relacjach $\mathrm{z}$ innymi podmiotami niż państwa ich siły winny być postrzegane jako aktorzy niepaństwowi (choć złożone z sił zbrojnych państw), lecz nie o takim samym charakterze jak inne niepaństwowe grupy zbrojne. Jeżeli zatem siły pokojowe ONZ występują przeciw niepaństwowym grupom zbrojnym, należy stwierdzić, że mamy do czynienia z niemiędzynarodowym konfliktem zbrojnym i w tym przypadku siły pokojowe ONZ mają obowiązek respektowania norm odnoszących się do niemiędzynarodowych konfliktów zbrojnych per analogiam ${ }^{35}$.

${ }^{34}$ T. Ferraro, op. cit., s. 596.

${ }^{35} \mathrm{Z}$ taką sytuacją mamy do czynienia w misji MONUSCO w Kongu, gdzie część pododdziałów misji tworząca Brygadę Interwencyjną (Intervention Force Brigade, IFB), została upoważniona do przeprowadzania ukierunkowanych operacji ofensywnych, jednostronnie lub wspólnie z FARDC, w sposób zdecydowany, wysoce mobilny i wszechstronny, zgodnie $\mathrm{z}$ prawem międzynarodowym, w tym międzynarodowym prawem humanitarnym, oraz z należytą starannością w zakresie praw człowieka, aby zapobiec ekspansji grup zbrojnych, zneutralizować te grupy i rozbroić je, aby ograniczyć zagrożenia stwarzane przez zbrojne grupy wobec władzy państwowej i bezpieczeństwa we wschodniej części DRK oraz stworzyć przestrzeń dla działań stabilizacyjnych, zob. Rezolucja RB ONZ z dnia 28 VI 2013 r., S/Res./2098, § 9, www.undocs.org (dostęp: 1 II 2020). Zob. S. Sheeran, S. Case, The Intervention Brigade...; L. Muller, The Force Intervention Brigade - United Nations Forces Beyond the Fine Line Between Peacekeeping and Peace Enforcement, "Journal of Conflict \& Security Law" 2015, vol. 20, no. 3, s. 359-381; F. Sperotto, Hic 
Do uznania sił pokojowych ONZ za stronę konfliktu zbrojnego konieczne jest więc prowadzenie przez te siły działań przeciw siłom rządowym lub grupom zbrojnym, także tym, które walczą z siłami rządowymi ${ }^{36}$. Takie działania sprawiaja, że siły pokojowe nie tylko zobowiązane są do respektowania norm $\mathrm{MPH}$, ale również stają się podmiotem, wobec którego normy te mogą być egzekwowane.

\section{Utożsamianie działań misji pokojowych ONZ z działalnością organizacji - kwestia alokacji odpowiedzialności}

Kwestia podziału i przyjęcia odpowiedzialności za naruszenie MPH między państwami a organizacją międzynarodową jest tematem szerokiej dyskusji. W odniesieniu do odpowiedzialności państw członkowskich za zobowiązania organizacji międzynarodowej ścierają się ze sobą trzy poglądy. Zgodnie z pierwszym odpowiedzialność państwa należy do podstawowych zasad prawa międzynarodowego i żadne państwo nie może się od niej uwolnić poprzez utworzenie organizacji międzynarodowej - odpowiedzialność organizacji ma jedynie charakter subsydiarny ${ }^{37}$. Według drugiego poglądu państwa człon-

Abundant Leones: The UN Combat Mission in the Democratic Republic of the Congo, "Global Jurist" 2014, no. 14, s. 101-120; D. Whittle, Peacekeeping in Conflict: The Intervention Brigade, MONUSCO, and the Humanitarian Law to United Nation Forces, "Georgetown Journal of International Law" 2015, no. 46, s. 831-875; O. Spijkers, The Evolution of United Nations Peacekeeping in the Congo, "Journal of International Peacekeeping" 2015, no. 19, s. 88-117.

${ }^{36}$ Takie podejście do definiowania rodzaju konfliktu i roli sił pokojowych ONZ zgodne jest z zaproponowaną przez Międzynarodowy Czerwony Krzyż teorią stosowania tzw. fragmented approach, z wykorzystaniem orzeczenia Nicaragua v. US. Sprowadza się ona do analizy relacji między walczącymi stronami z uwzględnieniem norm MPH. Stanowisko to podzielają zarówno Międzynarodowy Trybunał Karny, jak i Międzynarodowy Trybunał Karny ds. byłej Jugosławii, a także spotykane jest w literaturze przedmiotu. Zob. Decision on the Confirmation of Charges (Pre-Trial Chamber I) (The Prosecutor v. Lubanga Dyilo), Case No. ICC-01/04-01/06, 29 I 2007, § 209, Judgment (Trial Chamber I) (The Prosecutorv. Lubanga Dyilo), Case No. ICC-01/04-01/06, 14 III 2012,§ 536, 565; Decision on Defence Motion for Interlocutory Appeal on Jurisdiction (Prosecutor v. Tadic), $\$ 77$, a także T. Ferraro, op. cit., s. 596.

${ }^{37}$ T. Stein, Kosovo and the International Community. The Attribution of Possible Internationally Wrongful Acts: Responsibility of NATO or of Its Member States, w: Kosovo and the International Community, pod red. C. Tomuschata, The Hague 2002, s. 192 - autor publikacji przywołuje wspólną i solidarną (joint and several) odpowiedzialność państw członkowskich NATO za działania w Kosowie, opierając swoją opinię m.in. na ograniczonych możliwościach budżetu NATO. 
kowskie nie mogą odpowiadać za działania organizacji ze względu na odrębną podmiotowość międzynarodowa, chyba że traktat założycielski stanowi inaczej albo można znaleźć jakieś inne podstawy przypisania działania państwu ${ }^{38}$. Według trzeciego poglądu nie można stwierdzić obowiązywania żadnej reguły w tym zakresie, a wszelkie rozstrzygnięcia powinny być podejmowane w odniesieniu do danego przypadku, biorąc pod uwagę szczególne okoliczności sprawy oraz wszelkie stosowne dokumenty międzynarodowe, zwłaszcza traktaty założycielskie organizacji ${ }^{39}$.

Generalna zasada przyjęta w orzecznictwie międzynarodowym stanowi, że odpowiedzialność za działania, gdy w następstwie akcji wojskowej nastąpi naruszenie prawa, powinno ponosić to państwo, które sprawuje efektywną kontrolę nad personelem na danym obszarze poza swoim terytorium ${ }^{40}$. Nie ma zatem znaczenia sprawowanie ogólnej kontroli nad terytorium, gdyż jak stwierdził MTS, zbyt daleko rozciąga się więź, która musi istnieć między postępowaniem organu państwa a jego odpowiedzialnością międzynarodową ${ }^{41}$.

Problematyka odpowiedzialności organizacji międzynarodowej za działania personelu przekazanego przez państwa członkowskie do organizacji międzynarodowej, dokonane w trakcie wykonywania operacji porządkowania danej organizacji, była przedmiotem wielu rozstrzygnięć sądów międzynarodowych. O ile Międzynarodowy Trybunał Karny stał na stanowisku, że odpowiedzialność należy przypisać temu podmiotowi, który sprawuje kontrolę ogólną nad podmiotami biorącymi

${ }^{38}$ R. Higgins, The Legal Consequences for Member States of the Non-Fullfilment by International Organizations of their Obligations Toward Third Parties, "Annuaire de l'Institut de droit international" 1995, 66-1, s. 415.

${ }^{39}$ I. Seidl-Hohenveldern, International Economic Law, wyd. 2, Dordrecht-Boston-London 1992, s. 182-183, za: W. Czapliński, op. cit., s. 110; B. Krzan, op. cit., s. 168; UN Doc. A/CN.4/636, pkt II.B.29, s. 36. Zob też Draft Articles on the responsibility of international organisation, Report of the ICL, 2011, UN Doc.A/66/10.

${ }^{40}$ Wyrok ETPC w sprawie Loizidou przeciwko Turcji z 23 II 1995 r. (wstępne zastrzeżenia), nr skargi 15318/89, § 62.

${ }^{41}$ Military and Paramilitary Activities in and against Nicaragua (Nicaragua v. United States of America), Merits, Judgment, 27 VI 1986, ICJ Rep 1986. Trybunał podkreślił, że odpowiedzialność państwa za działania podmiotów niepaństwowych wchodzi w grę tylko w sytuacji ich całkowitej zależności od państwa albo pełnej kontroli państwa nad ich działaniami. Takie podejście można jednak uznać za nierealistyczne, gdyż spełnienie przesłanki całkowitej zależności czy pełnej kontroli nad podmiotami niepaństwowymi i przypisania odpowiedzialności państwu za ich działania może napotkać na trudności dowodowe, zob. J. Kranz, Standardy przypisania w kontekście międzynarodowej odpowiedzialności za użycie sity zbrojnej, „Kwartalnik Prawa Publicznego” 2009, nr 3-4, s. 26. 
udział bezpośrednio w operacji ${ }^{42}$, o tyle stanowisko Europejskiego Trybunału Praw Człowieka (ETPC) nie było już tak zasadnicze i ulegało zmianom w kolejnych orzeczeniach.

W sprawie Bankowić $i$ inni przeciwko Belgii i innym ${ }^{43}$ dotyczących nalotów NATO na Belgrad w 1999 r., opierając się na zasadzie tzw. ogólnej kontroli, ETPC uznał za niedopuszczalne rozszerzanie swojej jurysdykcji na organizację międzynarodową przeprowadzającą operację wojskową na danym terytorium. Oznaczało to pośrednio, że odpowiedzialność za działania przypisał organizacji, a nie państwom. Podobne rozstrzygnięcie zapadło w sprawie Berić i inni przeciwko BiH, w którym ETPC uznał, że efektywną pełną kontrolę nad operacją NATO w BiH sprawowała Rada Bezpieczeństwa, a zatem to ONZ, a nie NATO czy państwa członkowskie biorące udział w operacji winna ponosić odpowiedzialność za zabronione działania lub zaniechania personelu.

W kolejnych orzeczeniach zaczęto skłaniać się do przypisywania odpowiedzialności podmiotowi, który sprawuje faktyczną władzę nad jednostką w trakcie jego działania, uznając, że taką władzę sprawuje dane państwo pomimo wydzielenia swojego personelu do operacji nadzorowanej przez inny podmiot. Tak np. w sprawie Al-Skeinii i inni przeciwko Wielkiej Brytanii ${ }^{44}$ sąd zastosował model jurysdykcji personalnej nad funkcjonariuszem państwa, biorąc pod uwagę dwa czynniki, tj. kontrolę nad terytorium i jurysdykcję personalną. ETPC stwierdził, że za czyny objęte skargą odpowiedzialność ponosi nie ONZ, ale Wielka Brytania, która sprawowała w większym stopniu niż ONZ efektywną pełną kontrolę nad działaniami w południowym Iraku w ramach Międzynarodowych Sił Zadaniowych ${ }^{45}$.

Wspomniane rozstrzygnięcia dotyczyły jednak sytuacji, gdy pod auspicjami ONZ i na podstawie rezolucji Rady Bezpieczeństwa inna

${ }^{42}$ Decision on Defence Motion for Interlocutory Appeal on Jurisdiction (Prosecutor v. Tadic), § 137. Zob też A. Czaplińska, Odpowiedzialność organizacji międzynarodowych jako element uniwersalnego systemu odpowiedzialności międzynarodowej, Łódź 2014, s. 266.

${ }^{43}$ Decyzja ETPC z 12 XII 2001 r. w sprawie Banković i inni przeciwko Belgii i innym, skarga nr 52207/99.

${ }^{44}$ Al-Skeini and Others v. United Kingdom, Application no. 55721/07, Council of Europe: European Court of Human Rights, 7 VII 2011, https://www.refworld.org/cases,ECHR,4e2545502.html (dostęp: 1 II 2020).

${ }^{45}$ Zob. M. Szuniewicz, Operacje wojskowe autoryzowane przez Radę Bezpieczeństwa ONZ a problem odpowiedzialności międzynarodowej, VII Kolokwium Naukowe Praw Człowieka i Międzynarodowego Prawa Humanitarnego, Toruń, 4-5 XII 2014 r., s. 365, i zawarta tam analiza dotychczasowych ustaleń sądów międzynarodowych. 
organizacja lub koalicja państw prowadziła operację, w skład której wchodziły siły konkretnych państw. Kwestia odpowiedzialności stricte misji Narodów Zjednoczonych i państw wydzielających siły do nich nie była przedmiotem rozstrzygnięć sądowych.

Problematyką tą zajęła się Komisja Prawa Międzynarodowego ${ }^{46}$. W swojej ocenie przyjęła do analizy dwie możliwe sytuacje. Pierwsza ma miejsce, gdy państwo całkowicie oddaje do dyspozycji organizacji międzynarodowej pewne podmioty (swoje siły czy też pojedynczy personel), co wiąże się z tym, że ich postępowanie utożsamiane jest z wykonywaniem funkcji organizacji. Oznacza to, że organizacja w takim przypadku ponosi odpowiedzialność za ich działania. Druga sytuacja ma miejsce wtedy, gdy podmioty państwa przekazane organizacjom międzynarodowym nadal pozostają w pewnym stopniu podległe państwu, co skutkuje przypisaniem organizacji międzyrządowej odpowiedzialności za ich działania lub zaniechania tylko wtedy, gdy sprawuje ona efektywną kontrolę nad ich postępowaniem, co jest zbieżne $z$ orzecznictwem MTS.

Dowodzenie misją sprawuje głównodowodzący siłami misji ONZ. To on formułuje rozkazy operacyjne, które spływają do podległych mu operacyjnie pododdziałów. Dowódca kontyngentu narodowego dostosowuje ten rozkaz do swoich potrzeb i możliwości. Treść zawarta w jego rozkazie, a także sposób jego wykonania mogą być uzależnione od stosownych instrukcji narodowych. Ponadto państwo wysyłające może wprowadzić ograniczenia w wykonywaniu mandatu. Zastrzeżenia takie są przekazywane do głównodowodzącego misją w momencie przystępowania do udziału w misji, ale mogą być uzupełniane również w jej trakcie. Mogą one spowodować, że dowódca kontyngentu narodowego ma uprawnienie do odmowy wykonania rozkazu głównodowodzącego misją.

Jeżeli zatem personel kontyngentu narodowego pozostający pod ogólną władzą ONZ podejmuje konkretne działania lub też wzbrania się przed ich podjęciem ze względu na instrukcje pochodzące $z$ kraju, wówczas ich działania czy zaniechania powinny być przypisywane państwu, a nie organizacji ${ }^{47}$. A contrario można przyjąć, że w przypadku

${ }^{46}$ General Assembly, International Law Commission, Second Report on the Responsibility of International Organizations, A/CN.4/541 (2.4.2004), § 9; UN, Report of the International Law Commission, A/66/10 (2011), s. 88.

${ }^{47}$ Tak też ustalenia sądów krajowych odnoszące się do udziału wojsk belgijskich i holenderskich w ramach misji w Ruandzie i Bośni: wyrok w sprawie Mukeshimana-Ngulinzira i inni przeciwko Belgii i innym z 8 XII 2010 r., R.g. nr 04/4807/A i 07/15547/A, 
działań podejmowanych zgodnie z instrukcjami i rozkazami głównodowodzącego misją pokojową ONZ, które nie są działaniami ultra vires, pełną odpowiedzialność za takie działania i konsekwencje z nich wynikające winny spoczywać na organizacji międzynarodowej.

Ta trudność w ocenie, czy rozkaz został wykonany zgodnie z zaleceniami organizacji, czy też uwzględnił również narodowe instrukcje, nakazuje przyjąć pośrednie rozwiązanie. Odpowiedzialność za działania sił pokojowych ONZ powinna być subsydiarna i w zależności od konkretnego działania w większym lub mniejszym stopniu obciążać czy to organizację, czy państwo wydzielające siły do misji ${ }^{48}$, co zgodne jest z opisaną wyżej teoria, która nakazuje wszelkie rozstrzygnięcia podejmować w odniesieniu do danego przypadku, biorąc pod uwagę szczególne okoliczności sprawy oraz wszelkie stosowne dokumenty międzynarodowe, zwłaszcza traktaty założycielskie organizacji, a także procedury krajowe danego kontyngentu i zastrzeżenia, które do sposobu wykonania mandatu zgłosiło dane państwo.

\section{Podsumowanie}

Rozdział VII Karty Narodów Zjednoczonych dał możliwość tworzenia sił zbrojnych przez ONZ, przy założeniu, że kontyngenty narodowe państw przekazane do misji pokojowej miały wejść w pełną jej podległość. W praktyce aktywność państw ograniczyła się do wydzielenia swoich sił na potrzeby danej operacji. Państwa, pomimo przekazania władzy, zachowują uprawnienia do kontroli nad pododdziałami swoich sił zbrojnych, co nie wyłącza odpowiedzialności państw za działania swoich sił zbrojnych $w$ ramach danej organizacji. Za takim stanowiskiem przemawia fakt, że często organizacje międzynarodowe nie mają możliwości ustanowienia zasad kontroli i ich egzekwowania

ILDC 1604 (Be 2010), Court of First Instance of Brussels, Oxford Reports on International Law in Domestic Courts, vol. 1604; wyrok Sądu Apelacyjnego w Hadze w sprawie Nuhanovic z 5 VII 2011 r., LjN BR5388, ILDC 1742 (NL 2011), za: M. Szuniewicz, op. cit., s. 376.

${ }^{48}$ Istotny jest tu sposób realizacji mandatu. Ogólne postanowienie może brzmieć tak, że należy zrobić wszystko, co możliwe, do przywrócenia pokoju, a metody zastosowane przez dane siły mogą w praktyce oznaczać naruszenie norm MPH. Brak definicji neutralizacji i duża liczba pojęć niedookreślonych zawarta w mandacie sprawiły, że działania sił ONZ w Kongu zostały wykorzystane do walki o władzę w państwie, w celu wyeliminowania opozycyjnych przeciwników prowadzących działania zbrojne. 
względem sił wydzielonych przez państwa wykonujące zadania w imieniu organizacji ${ }^{49}$. Podlegają one kontroli operacyjnej, ale nie są pod dowództwem ONZ ${ }^{50}$. Pełna kontrola nad siłami zbrojnymi pozostaje w kompetencji państw narodowych, co oznacza, że dalej działają jako organy konkretnego państwa. Powoduje to wątpliwość w ustaleniu, kto faktycznie sprawuje kontrolę nad ich działaniem i czyje polecenia (rozkazy) są wykonywane ${ }^{51}$.

Operacje ONZ, przeprowadzane na podstawie mandatu udzielonego zgodnie z rozdziałami VI i VII Karty ONZ, spełniają istotną rolę w przywracaniu i utrzymywaniu pokoju i bezpieczeństwa. Jako instytucje powszechnie akceptowane przez społeczność międzynarodowa, powinny mieć zapewnioną ochronę w swoim działaniu. Niemniej jednak coraz częściej, pomimo zapewnień Rady Bezpieczeństwa, ze względu na swój mandat misje pokojowe ONZ nie respektują podstawowych reguł: bezstronności, użycia siły tylko w obronie własnej lub w obronie mandatu oraz zgody państwa goszczącego na obecność na swoim terytorium sił Narodów Zjednoczonych.

Konieczność konstruowania mandatów, które niejednokrotnie upoważniają do użycia siły, i to nie tylko w obronie własnej czy obronie mandatu, jest konsekwencją zmiany środowiska bezpieczeństwa, w którym przyszło funkcjonować misjom pokojowym ONZ. Takie działanie może jednak spowodować sytuację, w której siły pokojowe ONZ mogą zostać uznane za stronę konfliktu w rozumieniu $\mathrm{MPH}^{52}$. Choć Rada Bezpieczeństwa ONZ, jako organ polityczny społeczności międzynarodowej, jest w sposób nieskrępowany uprawniona do podejmowania decyzji w sprawie misji pokojowych ONZ i ich mandatu,

${ }^{49}$ M. Hirsch, The Responsibility of International Organizations Towards Third Parties, Dordrecht-Boston-London 1995, s. 107.

${ }^{50}$ United Nations Peacekeeping Operations: Principles and Guidelines, Department of Peacekeeping Operations, 2008, s. 68.

${ }^{51}$ Misje pokojowe ONZ przez Komisję Prawa Międzynarodowego zostały zaliczone do kategorii organów, których postępowanie jest przypisywane państwu wysyłającemu lub organizacji międzynarodowej na podstawie testu efektywnej kontroli, zob. General Assembly, International Law Commission, Second Report on the Responsibility of International Organizations, s. 26.

${ }^{52} \mathrm{Na}$ przykład po uchwaleniu mandatu misji MONUSCO rzecznik ruchu M23 oświadczył, że ze względu na udzielony Brygadzie Interwencyjnej mandat, może ona być podmiotem ataku.Ponadto oświadczył, że wobec braku wyraźnego oddzielenia od pozostałych sił MONUSCO, również pozostałe siły potencjalnie powinny być uważane za stronę konfliktu zbrojnego i są narażone na atak, zob. NGOs Concerned about New DRC Intervention Brigade, IRIN News, s. 10. 
pomimo sygnałów przekazywanych przez Sekretariat ONZ ${ }^{53}$ zdaje się nie dostrzegać tej kwestii i dalej działa w przekonaniu, że każdy atak na siły pokojowe ONZ jest złamaniem prawa międzynarodowego, a jego sprawcy powinni zostać osądzeni ${ }^{54}$.

Praktyka pokazuje, że granica między typowymi operacjami utrzymania pokoju a operacjami, w których ONZ prowadzi bardziej ofensywne działania ulega stopniowemu zatarciu ${ }^{55}$. O tym, czy siły pokojowe ONZ mogą być podmiotem, wobec którego mają zastosowanie normy $\mathrm{MPH}$, nie powinien decydować mandat ani inne wytyczne Sekretarza Generalnego ONZ, ale spełnienie przesłanek wynikających z MPH do uznania takich sił za stronę konfliktu.

W wielu przypadkach działalność misji pokojowych ONZ może prowadzić do naruszenia norm MPH. Pomimo uznawania misji pokojowych ONZ za organy pomocnicze organizacji, za które winna ona ponosić odpowiedzialność, kontyngenty narodowe nie są przekazywane pod wyłączną władzę organizacji i nie przestają działać jako organy państwa. W celu ustalenia odpowiedzialności za nieprzestrzeganie MPH konieczne jest w każdym przypadku dokonanie analizy zależności

${ }^{53}$ S. O'Brien, Statement by the Under-Secretary-General for Legal Affairs and UN Legal Counsel Delivered to the International Law Commission, Geneva 2013, http://legal.un.org/ ilc/sessions/65/Statement\%20byTheLegal\%20.Counsel.pdf (dostęp: 1 II 2020). Zob. też wypowiedź szefa misji MONUSCO, który jedynie potępił ataki na siły pokojowe ONZ, powstrzymując się od kwalifikowania tego czynu jako zbrodni wojennej (M. Kobler, Strongly Condemns the Killing of UN Peacekeeper by M23, Press Release, August 28, 2013).

${ }^{54}$ Pomimo wydania oświadczenia dla prasy dotyczącego misji w Kongu, gdzie stwierdzono, że celowy, bezpośredni atak na personel, instalacje, zasoby, pododdziały czy pojazdy zaangażowane w misję pokojowa, zgodnie z Kartą NZ, tak długo, jak są uprawnieni do korzystania z ochrony przysługującej osobom cywilnym czy cywilnym obiektom zgodnie z prawem międzynarodowych konfliktów zbrojnych, stanowi przestępstwo w rozumieniu prawa międzynarodowego, to jednak odnowienie rezolucji dotyczącej MONUSCO dalej zawierało sformułowanie, że jakiekolwiek ataki na siły pokojowe ONZ, bez wskazywania jakichkolwiek wyłączeń, będą traktowane jako zbrodnia wojenna, a sprawcy powinni zostać osądzeni. Zob. odpowiednio UN Security Council, Press Statement on Democratic Republic of Congo, UN Doc. SC/11108, August 29, 2013; Security Council Report, Democratic Republic of the Congo, July 2013 Monthly Forecast, New York, www.securitycouncilreport.org/monthly-forecast/2013-07/democratic_republic_of_the_congo_2.php; Rezolucja RB ONZ 2147 z dnia 28 VI 2014 r. przedłużająca misję MONUSCO, S/RES/2147 (dostęp: 1 II 2020).

${ }^{55}$ Wiele misji nazywanych misjami pokojowymi zgodnie z rezolucją RB ONZ działa na podstawie mandatu z rozdziału VII Karty, zob. Y. Arai-Takahashi, The Intervention Brigade...; Report Uniting Our Strengths for Peace: Politics, Partnership and People, High-Level Independent Panel on UN Peace Operations (HIPPO Report), UN Doc. A/70/95-S/2015/446, 2015, www.undocs.org (dostęp: 1 II 2020). 
między działaniami organizacji a działaniami sił danego państwa w ramach misji pokojowej oraz ustalenie systemu dowodzenia i „efektywnej” kontroli ${ }^{56}$.

\section{THE LIABILITY OF THE UNITED NATIONS PEACE OPERATIONS FOR VIOLATION OF INTERNATIONAL HUMANITARIAN LAW}

\section{S u m m a ry}

Operations under the auspices of the Security Council mandate span over 70 years. Repeatedly involved in resolving armed conflicts, they have made a significant contribution to ensuring security and stability around the world. In practice, they have taken the form of operations by individual states, coalitions, other international organizations or simply as United Nations missions composed of contingents provided by Troop Contribution Countries (TCC).

While operations under the auspices of the United Nations have been involved on several occasions in offensive activities under Chapter VII of the Charter of the United Nations, and the question of responsibility for these actions has been the subject of many legal analyses and judgments, missions organized by the United Nations are always recognized as neutral, and their activities as conciliatory and focused on monitoring the cessation of hostilities, or supervising the disengagement between the parties of the conflict, with the use of force limited to self-defence. Thus, such operations benefited from legal protection, and any action against them was considered a violation of international law.

The current engagement of United Nations goes far beyond the traditional understanding of peacekeeping operations. UN missions are frequently authorized to employ all necessary means, up to and including the use of lethal force or even neutralization of the armed group. This creates a situation where in the light of International Humanitarian Law, such actions can be recognized as involvement in armed conflict.

This article is intended to show the problems that the international community will soon face to in using United Nations' missions as an instrument for resolving armed conflicts and as a tool for restoring peace and providing stability and security in the area of operations.

It presents the processes of decision-making and subordination, which in some circumstances might result in the United Nations missions being deprived of legal protection and, in addition, made liable for non-compliance with the provisions of International Humanitarian Law.

Keywords: International Humanitarian Law - United Nations - Peacekeeping Operations - International Responsibility

${ }_{56}$ T.D. Gill, Legal Aspects of the Transfer of Authority in UN Peace Operations, "Netherlands Yearbook of International Law" 2011, vol. 42, s. 53. 


\section{LITERATURA}

Arai-Takahashi Y., The Intervention Brigade. The Intervention Brigade Within The MONUSCO. The Legal Challenges of Applicability and Application of IHL, "Questions of International Law" 2015, no. 5.

Boelaert-Suominen S., Commentary: The Yugoslav Tribunal and the Common Core of Humanitarian Law Applicable to All Conflicts, "Leiden Journal of International Law" 2000, no. 13.

Both M., Dorschel T., The UN Peacekeeping Experience, w: The Handbook of the Law of Visiting Forces, pod red. D. Flecka, Oxford 2001.

Czaplińska A., Odpowiedzialność organizacji międzynarodowych jako element uniwersalnego systemu odpowiedzialności międzynarodowej, Łódź 2014.

Czapliński W., Odpowiedzialność państwa członkowskiego za akty organizacji międzynarodowych, "Ruch Prawniczy, Ekonomiczny i Socjologiczny" 2006, R. 68, z. 2.

Engdahl O., A Rebuttal to Eric David, "International Review Red Cross” 2014, no. 95.

Ferraro T., The Applicability and Application of International Humanitarian Law to Multinational Force, „International Review of the Red Cross” 2013, vol. 95.

Fink J.E., From Peacemaking to Peace Enforcement: The Blurring of the Mandate for the Use of Force in Maintaining International Peace and Security, "Maryland Journal of International Law and Trade" 1995, no. 19.

Gill T.D., Legal Aspects of the Transfer of Authority in UN Peace Operations, „Netherlands Yearbook of International Law" 2011, vol. 42.

Henckaerts J.M. (red.), ICRC, Commentary on the First Geneva Convention: Convention (I) for the Amelioration of the Condition of the Wounded and Sick in Armed Forces in the Field, pod red. J.M. Henckaertsa, 2nd ed., 2016.

Higgins R., The Legal Consequences for Member States of the Non-Fullfilment by International Organizations of their Obligations Toward Third Parties, "Annuaire de l'Institut de droit international" 1995, 66-1.

Hirsch M., The Responsibility of International Organizations Towards Third Parties, Dordrecht-Boston-London 1995.

Kolb R., Applicability of International Humanitarian Law to Forces Under the Command of an International Organization, w: Report: Expert Meeting on Multinational Peace Operations Applicability of International Humanitarian Law and International Human Rights Law to UN Mandated Forces, pod red. A. Faite'a, J. Labbe Greniera, Geneva 2004.

Kranz J., Standardy przypisania w kontekście międzynarodowej odpowiedzialności za użycie sity zbrojnej, "Kwartalnik Prawa Publicznego” 2009, nr 3-4.

Krzan B., Odpowiedzialność państwa członkowskiego z tytułu działalności organizacji międzynarodowych, Wrocław 2013.

Muller L., The Force Intervention Brigade - United Nations Forces Beyond the Fine Line Between Peacekeeping and Peace Enforcement, "Journal of Conflict \& Security Law" 2015, vol. 20, no. 3.

Murphy R., UN Peacekeeping in Lebanon, Somalia and Kosovo: Operations and Legal Issues in Practice, Cambridge 2007.

Okimoto K., The Distinction and Relationship between Jus ad Bellum and Jus in Bello, Oxford 2011. 
Orakhelashvili A., Overlap and Convergence: The Interaction Between Jus ad Bellum and Jus in Bello, "Journal of Conflict and Security Law" 2007, no. 12.

Pejic J., The Protective Scope of Common Article 3: More Than Meets the Eye, "International Review of the Red Cross" 2011, vol. 93.

Picket J., Commentary on the Geneva Convention for the Amelioration of the Condition of the Wounded and Sick in Armed Forces in the Field, Geneva 1952.

Sams K.E., IHL Obligations of the UN in International Missions, w: International Military Missions and International Law, "International Humanitarian Law Series” 2011, t. 31.

Seidl-Hohenveldern I., International Economic Law, wyd. 2, Dordrecht-Boston-London 1992.

Seyersted F., United Nations Forces in the Law of Peace and War, Leyden 1966.

Sheeran S., Case S., The Intervention Brigade: Legal Issues for the UN in the Democratic Republic of the Congo, International Peace Institute, November 2014.

Sheeran S.P., A Constitutional Moment?: United Nations Peacekeeping in the Democratic Republic of Congo, "International Organizations Law Review" 2011, no. 1.

Shraga D., The United Nations as an Actor Bound by International Humanitarian Law, "International Peacekeeping" 1998, no. 5.

Shraga D., Zacklin R., The Applicability of International Humanitarian Law to United Nations Peacekeeping Operations: Conceptual, Legal and Practical Issues, Report to the Symposium on Humanitarian Action and Peacekeeping Operations, 22-24 June 1994, ICRC, Geneva 2004. 